\title{
The development of an enzyme-linked immunosorbent assay for Trypanosoma vivax antibodies and its use in epidemiological surveys
}

\author{
Claudio R Madruga ${ }^{+}$, Flábio R Araújo, Gustavo Cavalcante-Goes*, Charles Martins**, \\ Ingá B Pfeifer*, Laura R Ribeiro, Raul H Kessler, Cleber O Soares, Midori Miguita, \\ Elaine PS Melo, Robson FC Almeida, Manoel MSC Lima Jr.
}

\author{
Laboratório de Hemoparasitologia, Embrapa Gado de Corte, Br 262, km-4, 79002-970 Campo Grande, MS, Brasil \\ *Instituto de Ciências Biológicas, Universidade Federal do Pará, Belém, PA, Brasil **Escola de Veterinária Universidade \\ para o Desenvolvimento do Estado e da Região do Pantanal, Campo Grande, MS, Brasil
}

There are data indicating that the distribution of Trypanosoma vivax in the Brazilian territory is expanding with potential to reach other areas, where the vectors are present. The detection of anti-trypanosomal antibodies in serum provides important information of the trypanosomal status in cattle herds. For this reason, an enzyme-linked immunosorbent assay (Tv-ELISA-Ab) with crude antigen from one Brazilian isolate of $\mathrm{T}$. vivax was developed and evaluated. The sensitivity and specificity were respectively 97.6 and $96.9 \%$. In the evaluation of cross-reactions, three calves inoculated with $\mathrm{T}$. evansi trypimastigotes blood forms showed optical densities (OD) under the cut-off during the whole experimental period, except one at 45 days post-inoculation. With relation to Babesia bovis, B. bigemina, and Anaplasma marginale, which are endemic hemoparasites in the studied area, the cross-reactions were shown to be 5.7, 5.3, and 1.1\%, respectively. The first serological survey of Pantanal and state of Para showed that T. vivax is widespread, although regions within both areas had significantly different prevalences. Therefore, this $T$ V-ELISA-Ab may be a more appropriate test for epidemiological studies in developing countries because the diagnostic laboratories in most countries may be able to perform an ELISA, which is not true for polymerase chain reaction.

Key words: Trypanosoma vivax - enzyme-linked immunosorbent assay - epidemiological survey - cattle - Pantanal - Brazil

Trypanosoma vivax is a haemoprotozoan found in Africa, Central and South America. In Africa, the transmission occurs cyclically and mechanically but, in the New World (America) T. vivax is transmitted only mechanically by tabanids and other biting flies (Dwinger \& Hall 2000).

T. vivax was first reported in Brazil in 1946 parasitizing bovine in the state of Pará (Boulhosa 1946). Later, many other researchers reported the presence of T. vivax causing disease in bovines, ovines, caprines, and buffaloes in the same state (Shaw \& Lainson 1972, Didonet-Láu 1988).

The presence of this haemoprotozoan was reported only in this region until 1996, when it was diagnosed in cattle of Pantanal region of the state of Mato Grosso (Silva et al. 1996). One year later, T. vivax was found infecting beef cattle in the Pantanal region of Mato Grosso do Sul (Paiva et al. 1997). These data suggest that T. vivax is expanding its distribution in the Brazilian territory, with potential to reach other areas, where vectors (possibly tabanids) are present.

Financial support: Fundect/CNPq, Fundação Manoel de Barros ${ }^{+}$Corresponding author: madruga@cnpgc.embrapa.br Received 21 June 2006

Accepted 13 September 2006
As in other countries of South America, the trypanosomiasis outbreaks in cattle described in Pantanal were severe, since the herds showed high morbidity with fever, lethargy, anemia, loss of physical conditions, abortion, and mortality (Losos \& Ikede 1972, Dávila et al. 2003). According to Seidl et al. (1999), the economic impact due to $T$. vivax infection could exceed US\$ 160 million to the cattle industry in the Brazilian Pantanal and Bolivian lowlands. However, outbreaks with these characteristics are sporadic in Latin America countries where T. vivax occurs endemically, but the infection of this flagellate still being considered economically relevant (Otte et al. 1994).

One of the major parameters considered in modeling trypanosomosis control measures is the accurate assessment of the prevalence and/or incidence of the infection (Snow \& Rawlings 1999). The parasitological techniques are the most common for T. vivax diagnostic in Latin America as well as in Brazil. However, in infected animals the parasitemia fluctuates greatly and low number of parasites are present in the bloodstream during the chronic phase of the infection and often below the detectable by the usual parasitological diagnostic techniques (Mattioli $\&$ Faye 1996). The enzyme-linked immunosorbent assay (ELISA) that detects $T$. vivax antigen, initially described as more sensitive than Woo test (Masake et al. 1995), showed inferior field performance (Eisler et al. 1998). The polymerase chain reaction (PCR) had considerably improved the sensitivity of T. vivax diagnosis (Masake et al. 1997, Ventura et al. 2001), consequently showing ad- 
vantages over the parasitological diagnosis (Magona et al. 2003). However, the detection of anti-trypanosomal antibodies in serum provides accurate information on the trypanosomal status in cattle herds through prevalence determination (Connor \& Halliwell 1987, Mattioli et al. 2001).

The ELISA for detection of antibodies against trypanosome are often based on crude antigens which have shown instability and cross reactions between species of trypanosomes (Luckins 1977, Greiner et al. 1997). Recently, Rebeski et al. (2000b) concluded that plates precoated with crude antigen, air dried and stored over $4^{\circ} \mathrm{C}$ provided better performance than plates freshly coated with antigens kept frozen. However, Lejon et al. (2003) detected that the ELISA for $T$. vivax antibody detection in goats failed in consistency to detect the infected animals.

This paper firstly describes the development and evaluation of an ELISA with crude antigen of a Brazilian isolate of T. vivax. Secondly, reports seroepidemiological surveys in cattle of the Pantanal region in the state of Mato Grosso do Sul and in various micro regions in the state of Pará, Brazil.

\section{MATERIALS AND METHODS}

T. vivax isolate and parasitized blood - T. vivax was obtained from a naturally infected cow of the state of Mato Grosso, Pantanal wetlands, Brazil (GCTvPPO1-CO isolate). The stabilates produced with the infected blood of this cow were cryopreserved with $10 \%$ glycerol in liquid nitrogen. Two clinically healthy Nellore calves (12 months old) and negative for T. vivax determined by successive Woo parasitological exams (Woo 1969) were inoculated subcutaneously with the previously mentioned stabilate. Blood from these calves for the antigen preparation was collected in sodium heparin $(10 \mathrm{UI} / \mathrm{ml}$ of blood $)$ at parasitemia of approximately 40 trypomastigotes per microscopic field $(1000 \times$ magnification $)$.

T. vivax purification and antigen preparation - Two hundred milliliters of blood with the parasite concentration mentioned above were employed in each of the three procedures for the T. vivax purification. The first one was through centrifugation of parasitized blood at $1090 \times \mathrm{g}$ during $5 \mathrm{~min}$. Plasma just over the buffy coat was collected and centrifuged at $12,100 \times \mathrm{g}$. The second was done according to Barbosa (2000) for purification of T. cruzi. Shortly, the blood was centrifuged at $453 \times \mathrm{g}$ for $15 \mathrm{~min}$. The centrifuged tubes were placed in a water bath at $37^{\circ} \mathrm{C}$ for $15 \mathrm{~min}$ for parasite migration into the plasma. The plasma was transferred to other tubes and centrifuged at $2600 \times \mathrm{g}$ for $15 \mathrm{~min}$. The pellet was homogenized with Dulbecco's Modified Eagle's Medium (DMEM) containing $20 \%$ of fetal bovine serum in ice bath and after that was placed again at $37^{\circ} \mathrm{C}$ for $15 \mathrm{~min}$ for platelet agglutination. The platelet clumps were removed with a pipette aid and the remaining suspension was centrifuged at $2600 \times \mathrm{g}$ for $15 \mathrm{~min}$ to sediment the parasites. The parasites were suspended in DMEM at $-70^{\circ} \mathrm{C}$ until the antigen preparation. The third process was done according to Lanham and Goodfrey (1970) procedure. Shortly, DEAE-Sephadex columns (DE52, Whatman, catalog 4057050) were washed and equilibrated with phosphate saline buffer $\mathrm{pH} 8.0$ (9.5
$\mathrm{mM}, \mathrm{Na}_{2} \mathrm{HPO}_{4}, 5 \mathrm{mMNaH} \mathrm{PO}_{4} 2 \mathrm{H}_{2} \mathrm{O}, 72.6 \mathrm{mM} \mathrm{NaCl}$ ) containing $1 \%$ glucose (PSG) in a 4:6 range. The DEAESephadex slurry was placed carefully in Buchner funnels with filter paper (Whatman no. 41) on the botton. In the equilibrated and packed columns covered by filter paper (Whatman, no. 41) it was placed parasitized blood diluted 1:2 in PSG. The eluted T. vivax was saved in glass tubes and samples of each one were examined in the microscope to evaluate the parasite concentration. The eluted parasites were pooled and centrifuged at $1800 \times \mathrm{g}$ for $20 \mathrm{~min}$. The $T$. vivax pellet obtained from each purification method was mixed with lyses solution ( $100 \mathrm{mM}$ tris, $10 \mathrm{mM}$ EDTA, $0.2 \mathrm{mM} \mathrm{N}$ - $\alpha$-p-tosyl-L-lysil chloromethyl ketone, $2 \mathrm{mM}$ phenylmethyl sulfonylfluoride and $1 \%$ Nonidet P $40 \mathrm{v} / \mathrm{v}$ ). This suspension was homogenized in Toen-Broeck and kept at $4^{\circ} \mathrm{C}$ for $30 \mathrm{~min}$ and frozen at least overnight at $-70^{\circ} \mathrm{C}$. After thawing, this material was again homogenized in Toen-Broeck and sonicated at 100 Watts for $4 \mathrm{~min}$ (Branson Sonicator model 250, Branson Ultrasonics Corporation, US). Finally, the material was centrifuged at $12,100 \mathrm{x} \mathrm{g}$, at $4^{\circ} \mathrm{C}$ for $30 \mathrm{~min}$. The supernatants according the first, second, and third T. vivax purification procedure, were denominated as Pl-Tv, Ptf-Tv, and IEC-Tv antigens, respectively. The total protein concentrations were estimated by the Folin's reagent method and were $835 \mu \mathrm{g} /$ $\mathrm{ml}, 643 \mu \mathrm{g} / \mathrm{ml}$, and $574 \mu \mathrm{g} / \mathrm{ml}$, respectively. Aliquots of 100 $\mu 1$ of these antigens were stored at $-70^{\circ} \mathrm{C}$.

ELISA for detection of antibodies against T. vivax (Tv-ELISA-Ab) standardization - A series of experiments were performed to find the best antigen concentration, serum, conjugate dilutions, and substrate. The Pl-Tv, Ptf$\mathrm{Tv}$, and IEC-Tv antigens were diluted in such way to have the same concentration in all evaluations. It was found identical performances, therefore the first method was chosen, because it is simple, economical and less time consuming. The largest optical density difference between the mean optical density (OD) of positive (3) and negative (3) control sera was found by the protocol described below. Antigen diluted 1:1000 in Dubellccos's phosphate buffer solution $\left(1.47 \mathrm{mM} \mathrm{KH}_{2} \mathrm{PO}_{4} ; 154 \mathrm{mM} \mathrm{NaCl} ; 8.09 \mathrm{mM}\right.$ $\mathrm{Na}_{2} \mathrm{HPO}_{4}$ ), $\mathrm{pH} 7.3 \pm 0.1$ (DPBS) was added at volume of $100 \mu \mathrm{l}(20 \mathrm{\eta g} / \mathrm{well})$ in each well of polystyrene 96 well plate (Kima, ref. 655101). The antigen adsorption occurred during two hours at $37^{\circ} \mathrm{C}$ and subsequently, the plates were frozen overnight at $-20^{\circ} \mathrm{C}$. The plates were then thawed and washed five times with phosphate buffer saline (PBS) $\left(3.59 \mathrm{mM} \mathrm{Na} \mathrm{HPO}_{4} .2 \mathrm{H}_{2} \mathrm{O} ; 1.23 \mathrm{mM}\right.$ $\mathrm{NaH}_{2} \mathrm{PO}_{4} \mathrm{H}_{2} \mathrm{O} ; 99.2 \mathrm{mM} \mathrm{NaCl}$ ) containing $0.1 \%$ Tween-20 (PBST), $\mathrm{pH} 7.2$. Then, the plates were blocked with $100 \mu \mathrm{l} /$ well of DPBS containing $2 \%$ IgG-free equine serum (Sigma, ref. A-6917) and 5\% skim milk for $4 \mathrm{~h}$ at $4^{\circ} \mathrm{C}$ and frozen overnight at $-20^{\circ} \mathrm{C}$. After thawing, the plates were washed with PBST as described above. Four replicates of a strong positive, weak positive as well as negative sera controls diluted 1:1000 in PBST were placed in adjacent wells in the volume of $100 \mu \mathrm{l}$ of each microtitre plate. The same dilution and volume of test sera were placed into the wells in duplicate. After incubation for $45 \mathrm{~min}$ at $37^{\circ} \mathrm{C}$ and washing as described, bound antibodies were detected with 50 $\mu \mathrm{l} /$ well of rabbit anti-bovine $\mathrm{IgG}$ horseradish peroxidase conjugate (Sigma, ref. A-9169), diluted 1:10,000 in PBST. 
Microtitre plates were then incubated at $37^{\circ} \mathrm{C}$ for $30 \mathrm{~min}$ and after this incubation, the plates were washed as above, dried and in each well was added $50 \mu \mathrm{l} /$ well of o-phenyl diamine in a substrate solution. The reaction was stopped 10 min later by the addition of $100 \mu 1$ of $\mathrm{H}_{2} \mathrm{SO}_{4}(13.3 \%$ to each well). The results of the test were read in an ELISA reader at $490 \mathrm{~nm}$ filter (EL x 800, Bio-TekCorporation, US).

Cut-off establishment - The ELISA cut-off was determined with 128 cattle sera. One hundred and seven sera were from healthy cattle of the state of Rio Grande do Sul, Brazil, where T. vivax is not present. The remaining 21 sera were from calves raised in a diptera and tick-free isolation building at Embrapa Beef Cattle, Campo Grande, MS, Brazil. Although this area is considered T. vivax free, blood smears stained with May-Grunwald-Giemsa were examined before blood was collected to obtain sera. The cut-off was considered the OD mean of these sera plus three standard deviations. It was determined by plate and were accepted the plates with cut-off coefficient of variance equal or less than $5 \%$. The OD of these plates were adjusted to reference plate cut-off according formula described elsewhere (Madruga et al. 2000).

ELISA performance evaluation - Sensitivity was determined with 85 cattle sera. Sixty five sera were from cattle of Pantanal region of Mato Grosso do Sul, naturally infected with $T$. vivax as determined by the Woo test. The other 20 sera were from calves experimentally infected with $10^{7}$ T. vivax trypomastigotes.

Specificity was determined with 187 sera. One hundred and twenty five sera were of cattle raised in different periods in the isolation building and kept in the serum bank at Embrapa Beef Cattle. Additionally 62 sera from Pombal county of the state of Paraíba, considered free area for this hemoparasite, were tested.

Five Nellore 6-7 months-old calves were inoculated with $10^{7} \mathrm{~T}$. vivax trypomastigotes with the objective to determine the first detection and persistence of antibodies against $T$. vivax. During the experimental period, these animals were serologically monitored by TV-ELISA-Ab, parasitologically through May-Grunwald Giemsa stained blood smears from inoculation (day 0) and after that every 15 days until 60 days post-inoculation.

Cross-reactions with T. evansi antibodies were evaluated by experimental infection in three 6-10 month-old calves with $1.7 \times 10^{8}$ trypomastigotes of this species of trypanosome. Sera from these animals were collected until 90 days post-inoculation.

Cross reactions were also evaluated with sera from calves experimentally infected with A. marginale ( 89 sera), B. bovis ( 87 sera), and B. bigemina ( 95 sera) kept in the serum bank at Embrapa Beef Cattle. The indirect immunofluorescent antibody technique against Babesia organisms (Araújo et al. 1998a) and the A. marginale (Araújo et al.1998b) detected antibodies in all sera used for these cross reactions evaluations.

Seroepidemiological survey - A survey was carried out with sera from beef cattle (predominantly Nelore breed), of both sexes and varying ages, which were randomly selected from Corumbá (548 cattle sera), Porto
Murtinho (150 cattle sera), Miranda (214 cattle sera), Rio Verde (579 cattle sera), Rio Negro (501 cattle sera), and Aquidauana (516 cattle sera) counties of Pantanal region of Mato Grosso do Sul. This is a $138,000 \mathrm{~km}^{2}$ tropical seasonal wetland located in the center of South America, including part of Mato Grosso and Mato Grosso do Sul, between $16^{\circ} \mathrm{S}$ and $21^{\circ} \mathrm{S}$ and $55^{\circ} \mathrm{W}$ and $58^{\circ} \mathrm{W}$ and contains approximately 1100 extensive cattle ranches, varying from 10,000 to 200,000 hectares and three million cattle (Seidl et al. 1999).

A serological survey was also done in the state of Pará, localized between $2^{\circ} \mathrm{S}$ and $10^{\circ} \mathrm{S}$ and $46^{\circ} \mathrm{W}$ and $59^{\circ} \mathrm{W}$ in the equatorial area characterized as a tropical humid region. One thousand and fifty six cattle sera from five different regions of Pará, Marajó Island (101 cattle sera), Belém Metropolitan area (213 cattle sera), southwest (117 cattle sera), northeast (116 cattle sera), and southeast (509 cattle sera) were examined by Tv-ELISA-Ab. Most of the surveyed animals were beef cattle.

Statistical analysis - Data were analyzed by student test and qui square using the programs InStat and Prism 2 (GraphPad Software Inc.).

\section{RESULTS}

The crude soluble antigen produced from the three purification procedures showed identical performance in the standardized ELISA. This test resulted in a cut-off of 0.433 in the standard plate, considering the average OD of negative sera 0.232 plus 3 standard deviations. In the evaluation of positive sera two out of 85 sera samples from naturally and experimentally infected cattle were negative in the ELISA (Fig. 1) which corresponds to a sensitivity of $97.6 \%$. Six out of 187 negative sera had OD above the cut-off, giving a specificity of $96.9 \%$. All calves displayed seroconversion after the experimental inoculation that persisted until the end of the observation, except for one calf, as can be seen on Fig. 2. All three calves inoculated with T. evansi trypomastigotes showed OD under the cut-off during the whole experimental period, except one at the 45th day post-inoculation (Fig. 3). The sera of cattle with $B$. bovis, B. bigemina, and A. marginale infection, showed 5.7, 5.3, and $1.1 \%$, of cross-reactions, respectively, as can be seen on Fig. 4. The overall prevalence of T. vivax antibodies in the Pantanal of Mato Grosso do Sul and Pará can be seen in the Tables I, and II.

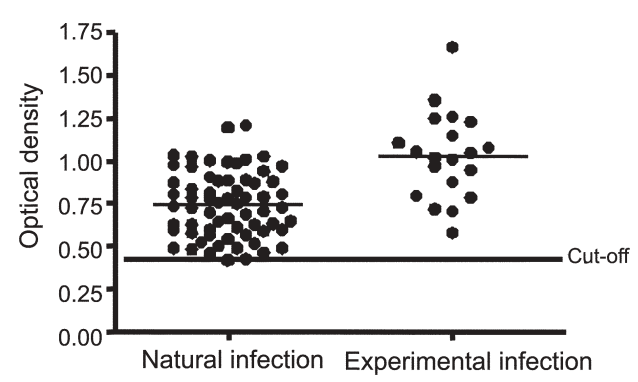

Fig 1: optical densities of the sera from parasited cattle of endemic area or experimentally infected for determination of the sensitivity by the enzyme linked immunosorbent assay with Trypanosoma vivax crude antigen for detection of antibodies. 


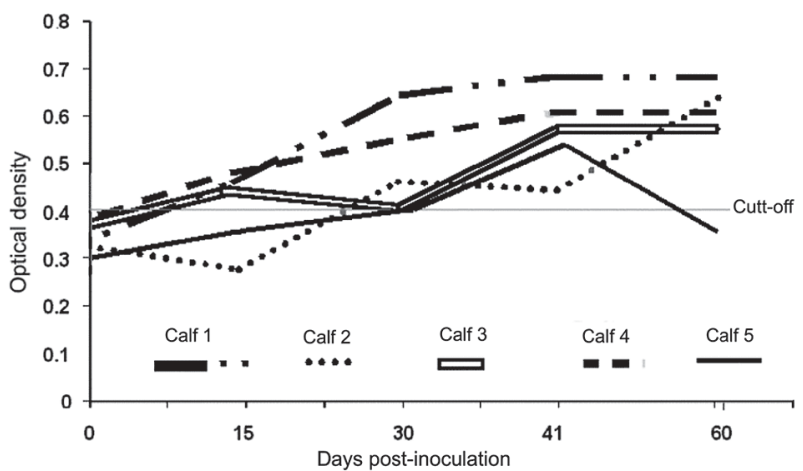

Fig 2: optical densities $(490 \mathrm{~nm})$ of the calves sera infected experimentally with Trypanosoma vivax tripamastigotes in the enzymelinked immunosorbent assay for antibody detection.

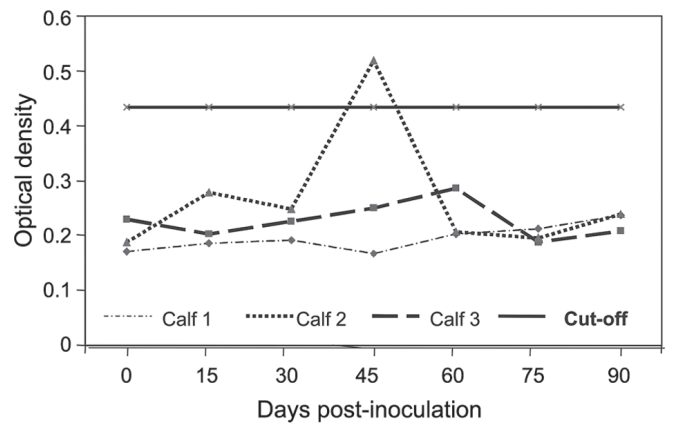

Fig 3: optical densities $(490 \mathrm{~nm})$ of sera from calves inoculated with $1.7 \times 10^{8}$ Trypanosoma evansi tripamastigotes in the enzyme-linked immunosorbent assay with crude antigen of Trypanosoma vivax for detection of antibodies.

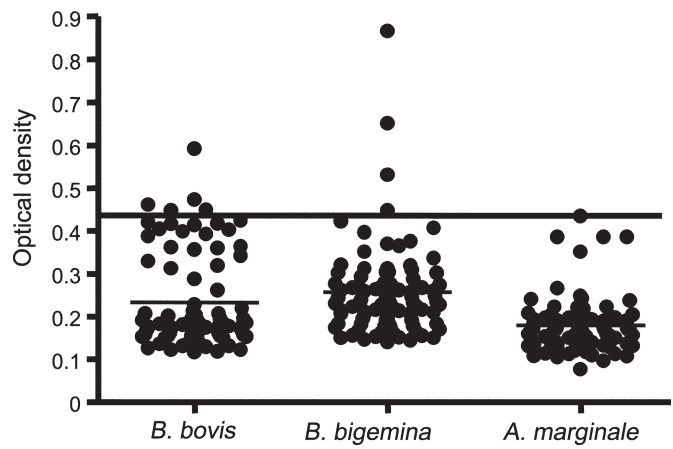

Fig. 4: optical densities of cattle sera with antibodies against Babesia bovis, Babesia bigemina, and Anaplasma marginale determined by enzyme-linked immunosorbent assay with crude antigen of Trypanosoma vivax.

\section{DISCUSSION}

All three $T$. vivax purification techniques yielded enough parasites for antigen production which did not differ in quality for the TV-ELISA-Ab. For this reason the centrifugation method was chosen because plasma recovery is simpler, less time consuming and economic. The Tv-ELISA-Ab displayed a sensitivity $(97.6 \%)$ which was similar to those determined by enzyme immunoassay with denatured $T$. vivax antigen $(95.1 \%$ ) reported by Rebeski et al. (2000a,b), and Hopkins et al. (1998) with eluate from dried blood spotted on filter paper $(96.8 \%)$. However the sensitivity of Tv-ELISA-Ab was considerably higher when compared with the latter ELISA that showed sensitivity

TABLE I

Prevalence of Trypanosoma vivax in six counties of the Pantanal region, state of Mato Grosso do Sul, Brazil, determined by enzyme-linked immunosorbent assay with crude antigen of this haemoprotozoan for detection of antibodies

\begin{tabular}{lccc}
\hline County & Cattle number & Positive sera & Prevalence $(\%)$ \\
\hline Corumbá & 548 & 394 & $71.9^{a}$ \\
Miranda & 214 & 127 & $59.3^{b}$ \\
Aquidauana & 516 & 359 & $69.6^{a}$ \\
Rio Negro & 501 & 141 & $28.1^{d}$ \\
Rio Verde & 579 & 298 & $51.5^{b, c}$ \\
Porto Murtinho & 150 & 86 & $57.3^{b, c}$ \\
\hline Total & 2508 & 1405 & 56
\end{tabular}

$a, b, c, d$ : statistical significance $(\mathrm{p}=0,05)$ between the prevalences of each county.

TABLE II

Prevalence of Trypanosoma vivax in five regions of the state of Pará, Brazil, determined by enzyme-linked immunosorbent assay with crude antigen of this haemoprotozoan for detection of antibodies

\begin{tabular}{lccc}
\hline Region & Cattle number & Positive sera & Prevalence (\%) \\
\hline Marajó Island & 101 & 70 & $69.3^{a}$ \\
Belem Metropolitan & 213 & 94 & $44.1^{b}$ \\
Southwest & 117 & 36 & $30.8^{c}$ \\
Northeast & 116 & 28 & $24.1^{c, d}$ \\
Southeast & 509 & 96 & $18.9^{d}$ \\
\hline Total & 1056 & 324 & 30.7
\end{tabular}

$a, b, c, d$ : letters indicated statistical significance $(\mathrm{p}=0,05)$ between the prevalences of each county. 
of $86.1 \%$, when performed with serum only instead serum impregnated in filter paper. The $96.6 \%$ specificity of TVELISA-Ab was also similar to other ELISA tests such as the ELISA with denaturated T. congolense antigen (94.2\%) or with $T$. vivax antigen using sera or bloodspots, 95.2 and $95.7 \%$, respectively (Hopkins et al. 1998).

Contrary to the ELISA described by Luckins (1977) for T. vivax antibodies in cattle, the Tv-ELISA-Ab differentiated $T$. evansi infections because only one cross reaction with sera of one of the calves experimentally infected with this species was observed. Cross reactions were expected because the crude antigens from whole trypanosomes are considered of limited subgenus specificity (Magona et al. 2003). The degree of T. evansi antigens involvement in the cross-reactions is not clear. On one side, at least one T. evansi variant surface glycoprotein (VSG), p64 induces antibody production that recognizes epitopes on the homologue T. vivax VSG (Uzcanga et al. 2004). On other side the lower number of variable antigen type (VAT) diversity displayed by Trypanozoon sub-genus, to which T. evansi fits in, compared to T. vivax could be a limitation for crossreactions (Meirvenne 1996). Perhaps, the high serum dilution compared to other ELISA tests, may contribute to the good sensitivity showed by Tv-ELISA-Ab. Despite sera dilution, the ELISA sensitivity was not reduced, since the mean of the first detection of antibodies occurred around 15 days after inoculation which do not differ from the ELISA with denatured antigen described by Rebeski et al. (2000b). Any way, the T. evansi infection at least in the Pantanal will not affect the seroprevalence studies, because Franke et al. (1994) found low seroprevalence of this species of trypanosome in bovines of northern Pantanal. Also, Davila et al. (2003) found a low percentage of cattle from Nhecolandia region, southern Pantanal, infected with $T$. evansi using polymerase chain reaction in the epidemiological study.

An advantage of the use of TV-ELISA-Ab in serological studies in Latin America is the absence of other trypanosome species that induce immune response which shows strong cross reactions in the ELISA with $T$. vivax crude antigen as occurs in Africa with $T$. congolense (Rebeski et al. 2000b). Another factor in favor of Tv-ELISA$\mathrm{Ab}$ is that T. theilleri, which occurs in South America, does not show cross reaction in the ELISA with $T$. vivax antigen (Luckins 1977). Although cross-reactions with $B$. divergens and $A$. marginale have not been verified (Luckins 1977), the Tv-ELISA-Ab exhibited a low percentage of cross reactions with $B$. bigemina, B. bovis, and $A$. marginale, blood parasites that occur endemically in the Pantanal and other Brazilian regions (Barros et al. 2005). Probably these reactions were restricted to an acute phase of primary infections of these hemoparasites, due to the immune response of some individuals that induced production of low affinity antibodies.

The evaluation of the TV-ELISA-Ab in epidemiological studies showed that $T$. vivax is present in the whole Pará with variable prevalences among the different microregions. This was expected because the presence of $T$. vivax in bovine, water buffalo and ovine has been reported in various locations of Pará for long time (Shaw \& Lainson 1972). The highest prevalence in Marajó Island and Belém metropolitan area is possibly related to wetlands of these areas that favor the mechanical transmission by tabanids and other haematophagous insects. In the Pantanal of Mato Grosso do Sul an endemic situation for T. vivax was also verified. It is important to mention this, the first diagnosis of this hemoprotozoan occurred nine years ago (Paiva et al. 1997). The only previous prevalence data in Pantanal was restricted to Nhecolandia microregion, determined by polymerase chain reaction (PCR). This study included buffalo, bovine, and sheep, and a prevalence of $42 \%$ was found (Davila et al. 2003), which is distinct of the overall prevalence of $56 \%$ found by the present serological survey which included six counties of the Pantanal of Mato Grosso do Sul. Also, the prevalences the Pantanal regions were significantly distinct. However, a clear conclusion is not possible, because the sampling methodology was not appropriate for a precise epidemiological evaluation. Indeed the seasonal factor was not considered, but it may be a determinant for the prevalence. The epidemiological study in the Nhecolandia found higher prevalence in the rainy season (Davila et al. 2003). During this period, flooding occurs during 5 to 6 months, resulting in an increased vector population and a reduced area of pasture which leads to higher cattle density per area and consequently to nutritional problems. Among the various biological factors that can determine the pattern of T. vivax infection, the nutritional one is reported to be important for the control of this infection, either under natural (Carmichael 1948) or experimental (Schenk et al. 2001) conditions. In the dry season, the environmental conditions favor a reduced $T$. vivax inoculation rate due to a lower vector population and better infection control by the host obtained by improved nutritional conditions. Seasonal variations and the nutritional host conditions have already seem to affect the $T$. vivax prevalence. Indeed, according to Authié et al. (1993), antibodies can persist up to 4 months following self cure. On the other hand, Bocquentin et al. (1990) observed that after parasite clearing by treatment, with 55 days the ELISA OD values become negative.

Based on the results, the Tv-ELISA-Ab showed to be suitable for seroepidemiological surveys and its development with a Brazilian T. vivax isolate was necessary because antigenic differences of trypanosomes from different geographical areas would affect the results of bovine trypanosome serology according to Rebeski et al. (2000b).

The Tv-ELISA-Ab allowed for the first time a seroprevalence study in regions of Brazil where T. vivax was previously diagnosed. This serological test is a diagnostic tool that permits better prevalence studies than the parasitological tests because it has significantly higher sensitivity (Mattioli et al. 2001). In our country the TvELISA-Ab may be more appropriate for epidemiological studies because most of the diagnostic laboratories can perform an ELISA test which is not true for PCR.

\section{REFERENCES}

Araujo FR, Madruga CR, Leal CRB, Schenk MAM, Kessler RH, Marques APC, Lemaire DC 1998a. Comparison between enzyme-linked immunosorbent assay, indirect fluorescent antibody and rapid conglutination tests in detecting 
antibodies against Babesia bovis. Vet Parasitol 74: 101108 .

Araújo FR, Madruga CR, Leal CRB, Bastos PAS, Marques APC 1998b. Freqüência de anticorpos anti-Anaplasma marginale em rebanhos leiteiros da Bahia. Arq Bras Med Vet Zootec 50: 243-246.

Authie E, Muteti DK, Willians DJL 1993. Antibody responses to invariant antigens of Trypanosoma congolense in cattle of differing susceptibility to trypanosomiasis. Parasite Immunol 15: 101-111.

Barbosa HS 2000. Manutenção e obtenção de diferentes estágios evolutivos em laboratório. In TC Araújo-Jorge, SL Castro (eds), Doença de Chagas. Manual para Experimentação Animal, Fiocruz, Rio de Janeiro, p. 184-195.

Barros SL, Madruga CR, Araújo FR, Menck CF, de Almeida MA, Melo EP, Kessler RH 2005. Serological survey of Babesia bovis, Babesia bigemina and Anaplasma marginale antibodies in cattle from semi-arid region of the state of Bahia, Brazil, by enzyme-linked immunosorbent assays. Mem Inst Oswaldo Cruz 100: 613-617.

Bocquentin R, Very P, Duvallet G 1990. Cinetique des anticorps après traitement trypanocide chez des bovins infectes experimentalement ou naturellement. Interet epidemiologique. Rev Elev Med Vet Pays Trop 43: 479-483.

Boulhosa J 1946. Informação Científica, Boletim Técnico Ministério da Agricultura, p. 21-26.

Carmichael J 1948. The epidemiology of trypanosomiasis in man and animals. JR Soc Med 41: 551.

Connor RJ, Halliwell RW 1987. Bovine trypanosomiasis in southern Tanzania: parasitological and serological survey of prevalence. Trop Anim Health Prod 19: 165-172.

Davila AMR, Herrera HM, Schlenbinger T, Souza SS, TraubCseko YM 2003. Using PCR for unraveling the cryptic epizootiology of livestock trypanosomiasis in the Pantanal, Brazil. Vet Parasitol 117: 1-13.

Didonet-Lau H 1988. Sintomas e tratamento da tripanossomíase (T. vivax) em búfalos. Embrapa-CPATU, Belém, 13 pp. (Boletim de Pesquisa, 90).

Dwinger RH, Hall MJR 2000. Trypanosomosis due to Trypanosoma vivax in ruminants in Latin America. In Animal Tripanosomosis: Diagnosis and Epidemiology, FAO, Roma, p. 50-55.

Eisler MC, Lessard P, Peregrine AS, Masake RA, Moloo SK, 1998. Sensitivity and specificity of antigen-capture ELISAs for diagnosis of Trypanosoma congolense and Trypanosoma vivax infections in cattle. Vet Parasitol 79: 187-201.

Franke CR, Greiner M, Mehlitz D 1994. Monitoring of clinical, parasitological and serological parameters during an experimental infection of capybaras (Hydrochaeris hydrochaeris) with Trypanosoma evansi. Acta Trop 58: 159-169.

Greiner M, Bhat TS, Patzelt RJ, Kakaire D, Schares G, Dietz E, Bohning D, Zessin KH, Mehlitz D 1997. Impact of biological factors on the interpretation of bovine trypanosomosis serology. Prev Vet Med 30: 61-73.

Hopkins JS, Chitambo H, Machila N, Luckins AG, Rae PF, van den Bossche P, Eisler MC 1998. Adaptation and validation of antibody-ELISA using dried blood spots on filter paper for epidemiological surveys of tsetse-transmitted trypa- nosomosis in cattle. Prev Vet Med 37: 91-99.

Lanham SM, Godfrey DG 1970. Isolation of salivarian trypanosomes from man and other mammals using DEAE-cellulose. Exp Parasitol 28: 521-534.

Lejon V, Rebeski DE, Ndao M, Baelmans R, Winger EM, Faye D, Geerts S, Buscher P 2003. Performance of enzyme-linked immunosorbent assays for detection of antibodies against T. congolense and T. vivax in goats. Vet Parasitol 116: 8795.

Losos GJ, Ikede BO 1972. Review of pathology of diseases in domestic and laboratory animals caused by Trypanosma congolense, T. vivax, T. brucei, T. rhodesiense and $T$. gambiense. Vet Pathol 9: 53-62.

Luckins AG 1977. Detection of antibodies in trypanosomeinfected cattle by means of a microplate enzyme-linked immunosorbent assay. Trop Anim Health Prod 9: 53-62.

Madruga CR, Marques APC, Leal CRB, Carvalho CME, Araújo FR, Kessler RH 2000. Evaluation of an enzyme-linked immunosorbent assay to detect antibodies against Anaplasma marginale. Pesq Vet Bras 20: 109-112.

Magona JW, Mayend DJS, Olaho-Mukani W, Coleman PG, Jonson NN, Welburn SC, Eisler MC 2003. A comparative study on the clinical, parasitological and molecular diagnosis of bovine tripanosomosis in Uganda. Onderstepoort $J$ Vet Res 70: 213-218.

Masake RA, Moloo SK, Nantulya VM, Minja SH, Makau JM, Njuguna JT 1995. Comparative sensitivity of antigen-detection enzyme immunosorbent assay and microhaematocrit centrifugation technique in the diagnosis of Trypanosoma . brucei infections in cattle. Vet Parasitol 56: 37-46.

Masake RA, Majiwa PAO, Moloo SK, Makau MJ, Njuguna JT, Maina M, Kabata J, Ole-MoiYoi OK, Nantulya VM, 1997. Sensitive and specific detection of Trypanosoma vivax using the polymerase chain reaction. Exp Parasitol 85: 193205.

Mattioli RC, Faye JA 1996. A comparative study of the parasitological buffy coat technique and an antigen enzyme immunoassay for trypanosome diagnosis in sequential Trypanosoma congolense infections in N'Dama, Gobra zebu and N'Dama x Gobra crossbred cattle. Acta Trop 62: 71-81.

Mattioli RC, Faye JA, Jaitner J 2001. Estimation of trypanosomal status by the buffy coat technique and an antibody ELISA for assessment of the impact of trypanosomosis on health and productivity of N'Dama cattle in The Gambia. Vet Parasitol 95: 25-35.

Meirvenne NV 1996. Antibody detection tests for diagnosis of African trypanosomosis. Antigen ELISAS for trypanosomes. Evaluation performance. In Proceedings of a Workshop Held at ILRI, Nairobi, Kenya, p.105-106.

Otte MJ, Abuabara JY, Wells EA 1994. Trypanosoma vivax in Colômbia: epidemiology and production losses. Trop Anim Health Prod 26: 146-156.

Paiva F, Lemos RAA, Oshiro ET, Salvador SC, Nakazato L 1997. Ocorrência de Trypanosoma vivax em bovinos no Estado de Mato Grosso do Sul. Rev Bras Parasitol Vet 6 (Sup.1): 349.

Rebeski DE, Winger EM, Robinson MM, Gabler CMG, Dwinger RH, Crowther JR, 2000a. Evaluation of antigencoating procedures of enzyme-linked immunosorbent as- 
say method for detection of trypanosomal antibodies. Vet Parasitol 90: 1-13.

Rebeski DE, Winger EM, Okoro H, Kowaliki S, Burger HJ, Walters DE, Robinson MM, Dwinger RH, Crowther JR 2000b. Detection of Trypanosoma congolense antibodies with indirect ELISAs using antigen-precoated microtitre plates. Vet Parasitol 90: 187-198.

Schenk MAM, Mendonça CL, Madruga CR, Kohayagawa A, Araújo FR 2001. Avaliação clínico-laboratorial de bovinos Nelore infectados experimentalmente com Trypanosoma vivax. Pesq Vet Bras 21: 157-161.

Seidl A, Dávila AM, Silva RA 1999. Estimated financial impact of Trypanosoma vivax on the Brazilian Pantanal and Bolivian lowlands. Mem Inst Oswaldo Cruz 94: 269-272.

Shaw JJ, Lainson R 1972. Trypanosoma vivax in Brazil. Ann Trop Med Parasitol 66: 25-32.

Silva RA, da Silva JA, Schneider RC, de Freitas J, Mesquita D, Mesquita T, Ramirez L, Davila AM, Pereira ME 1996.
Outbreak of trypanosomiasis due to Trypanosoma vivax (Ziemann, 1905) in bovines of the Pantanal, Brazil. Mem Inst Oswaldo Cruz 91: 561-562.

Snow WF, Rawlings P 1999. Methods for the rapid appraisal of African animal trypanosomosis in the Gambia. Prev Vet Med 42: 67-86.

Uzcanga GL, Perrone T, Noda JA, Perez-Pazos J, Medina R, Hoebeke J, Bubis J 2004. Variant surface glycoprotein from Tripanosoma evansi is partially responsible for the cross reaction between Tripanosoma evansi and Trypanosoma vivax. Biochemistry 43: 595-606

Ventura RM, Paiva F, Silva RA, Takeda GF, Buck GA, Teixeira MM 2001. Trypanosoma vivax: characterization of the spliced leader gene of the Brazilian stock and species specific detection by PCR amplification of intergenic spacer sequence. Exp Parasitol 99: 37-48

Woo PTK 1969. The hematocrit centrifuge for the detection of trypanossomose in blood. Can J Zool 47: 921. 